\title{
PERBAIKAN KINERJA OPERASIONAL INDUSTRI PENYAMAKAN KULIT DENGAN PENDEKATAN SUPPLY CHAIN DAN LEAN MANUFACTURING (Kasus Industri Kulit Sukaregang)
}

\author{
Muhamad Dzikron ${ }^{1}$, Rakhmat Ceha ${ }^{2}$, Chaznin R Muhammad ${ }^{3}$ \\ Jurusan Teknik Industri, Fakultas Teknik, Universitas Islam Bandung ${ }^{1,2,3)}$ \\ Jl. Taman Sari No.1, Bandung, Jawa Barat, 40116 \\ E-Mail :mdzikron@gmail.com ${ }^{1}$
}

\begin{abstract}
The industrial sector drive the economy. One of the sub-sectors that have economic potential is a leather and leather garment industry. But the leather industry conditions generally inefficient. In recent years the leather industry there are obstacles to lack of supply of raw materials, and industrial utilization rate is low. Supply of raw materials depend on import of raw leather, medium leather industry utilization during 2010-2015 an average of 50.13\%. The low utilization rate reflects the performance of inefficient operation. Responding to the above problems, the approach to lean manufacturing and supply chain management can be applied to improve the performance of the industry. Lean manufacturing in an effort to minimize the efficiency of industrial activities that are not value-added. For the next lean manufacturing approach integrated into industrial relations by the method of Supply Chain so hopefully improve industrial performance and add value. The study begins with business process mapping methods Integrated Definition for Function Modeling (IDEFØ) to identify business processes factually. From the analysis of the process bisniskemudian mapping value chains and identification of critical processes in the leather industry. Furthermore, in design improvements with Lean manufacturing, refers to the concept of value-stream mapping to identify non-value added activities in industrial systems.
\end{abstract}

Keywords: Leather, Lean Manufacturing, Supply Chain; Performance, Value Chain.

\section{PENDAHULUAN}

Sektor Industri berperan penting dalam pembangunan ekonomi. Salah satu subsektor industri memiliki berpotensi di pasar dunia adalah industri kulit. Kinerja ekspor Industri kulit ditunjukkan tabel 1 yang menunjukan perkembangan ekspor kulit dan barang dari kulit sebagai ber fluktuasi. Ekspor produk kulit berdasar harga ekspor di kapal (FOB) pada tahun 2010 sebesar 207.015 juta USD. Tahun 2011 nilai ekspor naik 12,19 ribu ton, menjadi US\$230,14 juta.

Namun tahun 2012 nilai ekspor turun menjadi US $\$ 214,7$ juta atau berkurang 10,66 ribu ton. Pada tahun 2013, nilai ekspor naik $3,65 \%$ menjadi US $\$ 222,6$ juta. Pada tahun 2014 nilai ekspor kembali turun menjadi 209.328 atau berkurang sebesar $-5,98 \%$ dari tahun sebelumnya. Catatan beberapa negara tujuan ekspor antara lain Hongkong sebesar
US\$45,43 juta, Amerika Serikat US\$33,40 juta, Vietnam US\$26,83 juta, dan Tiongkok sebesar US\$21,60 juta.

Provinsi Jawa Barat memiliki sentra produksi kulit yang terkenal yaitu industri kulit Sukaregang di kabupaten Garut. Industri kulit Sukaregang adalah klaster industri yang memiliki keterkaitan hulu - hilir secara lengkap. Sentra ini mengolah kulit mentah menjadi kulit tersamak (industri hulu) yang memiliki nilai tambah tinggi, dan selanjutnya kulit tersamak ini menjadi input bagi industri garmen kulit dan kerajinan kulit. Beberapa produk industri adalah jaket kulit, tas, sepatu kulit, dompet dan sebagainya. Berbagai produk kulit dikenal sebagai komoditas perdagangan di tingkat lokal, nasional sampai ekspor. 
Tabel 1. Perkembangan Ekspor Kulit dan Barang dari Kulit Tahun 2007-2014 (Sumber: BPS dan Kemenperin 2014)

\begin{tabular}{c|c|c|c}
\hline Tahun & $\begin{array}{c}\text { Berat Bersih } \\
\text { (Ton) }\end{array}$ & $\begin{array}{c}\text { Nilai FOB } \\
\text { (US ribu \$) }\end{array}$ & $\begin{array}{c}\text { Perubahan } \\
\text { (\%) }\end{array}$ \\
\hline 2007 & 12.101 & 226.895 & 27,84 \\
2008 & 11.411 & 226.773 & $-0,05$ \\
2009 & 10.743 & 174.836 & $-22,90$ \\
2010 & 13.223 & 207.015 & 18,41 \\
2011 & 12.187 & 230.148 & 11,17 \\
2012 & 10.663 & 214.790 & $-6,67$ \\
2013 & 10.719 & 222.631 & 3,65 \\
2014 & 11.254 & 209.328 & $-5,98$ \\
\hline
\end{tabular}

Industri kulit nasional berkembang terutama pada masa tahun 1970 -an, ditandai munculnya beberapa sentra industri seperti sentra penjualan Tanggulangin Sidoardjo, sentra penyamakan kulit Magetan Jawa Timur, sentra penjualan Yogyakarta, sentra produksi dan penjualan di Sukaregang Garut serta sentra penjualan Cibaduyut-Bandung. Selama ini proses pengolahan kulit didasarkan pada ketrampilan pekerja yang didapat secara turun temurun (USAID, 2007). Potensi sentra Industri kulit menjadi tantangan dalam pertumbuhan ekonomi. Namun sektor industri memiliki permasalahan rendahnya kinerja. Beberapa permasalahan industri adalah ketersediaan bahan baku, akses permodalan dan pemasaran, daya saing, mutu produk, desain belum berorientasi ekspor serta rendahnya kemampuan manajemen dan teknologi (Departemen Perindustrian, 2008, Kemenperin 2015).

\subsection{Permasalahan}

Industri kulit Sukaregang memiliki permasalahan internal berupa pemborosan sumber daya, utilisasi, dan permasalahan eksternal dalam hubungan antarindustri. Selain itu juga terdapat kendala pasokan bahan baku kulit mentah yang diimpor dari luar negeri. Secara konseptual terdapat teori untuk meningkatkan kinerja operasional industri dengan metode lean manufacturing untuk menghilangkan aktivitas - aktivitas yang tidak memberikan nilai tambah (nonvalue added activities) dalam proses bisnis perusahaan.
Sentra Industri Sukaregang sebagai sentra kulit utama di Jawa Barat. Data industri menurut Unit Pelaksana Teknis Daerah Balai Pengembangan Perindustrian Jawa Barat, terdapat 267 unit usaha penyamakan kulit (UPTD BPP, 2015). Dalam mengoptimalkan pengembangan industri UPTD membentuk Sub Unit Pengembangan Penyamakan Kulit. Sedang menurut Asosiasi Penyamakan Kulit Indonesia (APKI) Garut jumlah pengusaha menengah yang memiliki mesin pengolahan ada 52 unit. Pengusaha menengah yang bertindak sebagai perusahaan induk, sedang pengusaha kecil yang tidak memiliki mesin menitipkan proses (makloon) kepada perusahaan besar.

Perkembangan industri kulit Sukaregang dalam beberapa tahun terakhir (2010 - 2015) mengalami kekurangan pasokan bahan baku kulit sapi sehingga diimpor dari Australia dan Selandia Baru. Dalam hal ini kekurangan bahan baku kulit kambing / domba didatangkan dari provinsi lain seperti Nusa Tenggara Barat (NTB), Nusa Tenggara Timur (NTT), Jawa Timur dan Sumatera. Kurangnya pasokan kulit mentah menggangu proses produksi, dan kualitas serta daya saing produk yang rendah. Kondisi kurangnya pasokan menambah beban biaya produksi, berdampak distribusi produk terlambat. Industri Sukaregang belum menunjukkan kinerja yang baik, daya saing di pasar nasional dan pasar ekspor masih lemah (Dinas Indag \& Kop Garut, 2015). 
Adapun kinerja industri kulit dalam aspek utilisasi terkategori rendah, sebagaimana utilisasi tahun 2010 - 2015 . Tingkat utilisasi industri kulit tahun 2010 sebesar 45,72\%; $2011 \quad(44,06 \%) ; 2012$ (51,34\%); 2013 (51,76\%); 2014 (52,24\%) dan tahun $2015(53,64 \%)$. Secara rata-rata tingkat utilisasi adalah $50,13 \%$ hal ini mencerminkan kapasitas tidak efisien atau fasilitas industri kulit 49,87\% menganggur (Vanessa \&Obrina, 2016). Rendahnya Utilisasi adalah bentuk pemborosan sumber daya. Selain rendahnya utilisasi terdapat masalah inefisiensi inventory bahan kimia impor yang menumpuk.

Persoalan ini merupakan gambaran industri kulit (SMEs) dimana permintaan pasar domestik terhadap kulit untuk konsumen menengah atas dimasuki pelaku industri kulit dari luar negeri. Situasi ini menyebabkan industri kulit dalam negeri menghadapi tantangan berat. Oleh karena itu, perlu perbaikan kinerja internal perusahaan dalam memenuhi kebutuhan pasar. Industri kerajinan kulit memiliki keterkaitan ke belakang (backward linkages) dan ke depan (forward linkages), sehingga dapat menumbuh kembangkan industri hulu (penyamakan), industri pendukung, dan industri terkait lainnya. Kinerja industri kulit Sukaregang perlu ditingkatkan untuk menghasilkan produk yang berkualitas secara lebih baik (better), lebih murah (cheaper) dan dalam waktu yang lebih singkat (faster). Sehingga produk yang dihasilkan memiliki nilai tambah lebih besar dan memberikan manfaat bagi industri kulit itu sendiri, industri pendukung dan industri terkait lainnya.

\subsection{Tujuan Penelitian}

Tujuan penelitian adalah meningkatkan kinerja industri penyamakan pada sentra industri kulit Sukaregang - Garut. Peningkatan kinerja industri didasarkan bahwa industri kulit adalah industri potensial. Kapasitas industri menurut Asosiasi Penyamakan Kulit Indonesia (APKI, 2014) sampai saat ini baru memenuhi permintaan pasar sekitar 20\%. Industri kulit nasional menghasilkan produk kulit rata - rata 60 juta feet 2 / tahun sementara permintaan pasar mencapai 300 juta feet 2 / tahun. Salah satu penyebab ketidakmampuan memenuhi permintaan adalah kekurangan pasokan bahan baku kulit. Kekurangan bahan baku dipenuhi melalui impor kulit mentah termasuk impor bahan kimia untuk proses penyamakan. Dampak kurangnya pasokan bahan baku mempengaruhi kinerja proses bisnis secara internal dan hubungan antarindustri. Oleh karena itu, penelitian ini dilakukan dalam pendekatan Lean manufacturing yang diterapkan untuk mengidentifikasi non-value-added activities dan value-added activities menuju perbaikan kinerja industri kulit secara internal dan eksternal.

\section{TINJAUAN PUSTAKA}

Penelitian tentang integrasi industri dalam konsep supply chain dan lean manufacturing untuk memperbaiki kinerja industri telah dibahas oleh beberapa peneliti. Diawali dari perkembangan konsep Lean Manufacturing adalah sistem produksi di industri otomotif Toyota Production System. Pendekatan Toyota Production System kemudian dikenal sebagai "Lean" (Womack, 1990; Holweg, 2007). Lean berarti ramping, suatu industri disebut Lean jika semua aktivitas yang dilakukan tidak bersifat boros 'non-wasted', memberikan nilai tambah 'value-added' bagi customer. Lean sebagai pendekatan sistematik untuk mengidentifikasi dan menghilangkan pemborosan (waste) dan meningkatkan nilai tambah (value added) produk kepada konsumen (customer value).

Keterkaiatan Lean manufacturing dan supply chain management (SCM) pada industri manufaktur dan jasa dikemukakan oleh Cudney \& Elrod (2011) dengan implementasi Lean manufacturing pada jalur pemasok (supplier). Peningkatan daya saing industri dengan pendekatan Lean manufacturing sebagai best practices dalam simplifikasi dan eliminasi waste atas prosesaktivitas yang kompleks juga dilakukan oleh So dan Sun (2010). 
Sedang penelitian lean production dalam supply chain management juga dilakukan oleh Agus \& Hajnoor (2012) yang meneliti perusahaan manufaktur di Malaysia. Hasil penelitian memperlihatkan hubungan yang kuat antara lean production dengan kualitas produk, dan kinerja bisnis perusahaan. Dalam hal ini, tinjauan penelitian mengarah kepada model perbaikan supply chain (SC) pada industri kulit untuk meningkatkan kinerja industri. Produk - produk kulit yang digunakan bukan berasal dari satu industri yang terpisah, tetapi berasal dari suatu rantai industri yang terintegrasi. Hal ini sebagaimana tahapan dalam SC, mulai dari pemilihan dan pembelian bahan baku dan komponen pendukung, proses produksi, marketing, distribusi dan penjualan, dan diakhiri dengan permintaan konsumen baik domestik maupun ekspor. Value SC adalah tersedianya pendekatan terintegrasi untuk menganalisis hambatan sepanjang SC yang kemudian menghasilkan solusi menyeluruh.

Rangkaian pihak - pihak yang menangani aliran produk disebut Supply Chain (SC). Sebuah supply chain memiliki komponen-komponen yang disebut channel. Channel tersebut seperti supplier, manufaktur, distribution center, wholesaler, dan retailer. Semua channel bekerja untuk memenuhi kebutuhan konsumen akhir. SC melibatkan sejumlah industri manufaktur dalam satu rantai hulu ke hilir. Produk atau jasa adalah hasil rangkaian proses panjang yang melewati beberapa tahapan baik intra maupun inter perusahaan. Proses intra perusahaan adalah proses operasi secara internal dalam proses produksi. Sedangkan proses inter perusahaan adalah rangkaian dua atau lebih perusahaan termasuk pemasok dan konsumen, seperti pasokan bahan baku dan distribusi atau transportasi.

Proses didefinisikan sebagai kegiatan berkelanjutan dan teratur dilakukan dengan cara tertentu dan bertujuan mencapai suatu hasil. Lebih jauh proses diartikan sebagai aktivitas-aktivitas dengan satu jenis input atau lebih yang dilakukan untuk menciptakan output yang bernilai bagi pelanggan. Kata kunci ini adalah penataan ulang proses bisnis, bukan tugas (task), pekerjaan (job), orang dan bukan struktur. Sedangkan proses bisnis adalah rangkaian aktivitas untuk mengubah inputs menjadi sejumlah outputs (barang dan jasa) dengan yang menggunakan orang dan alat.

IDEF merupakan kepanjangan dari Metode Integrated Definition. IDEFØ (dibaca : IDEF Zero) merupakan suatu pemodelan statis yang merepresentasikan sebuah sistem sebagai suatu jaringan dari beberapa aktivitas yang memiliki keterkaitan. IDEFØ adalah subset standar dari sebuah paradigma umum, biasa disebut Structured Analysis and Design Technique (SADT), IDEFØ adalah paradigma pemodelan intend untuk pemodelan sistem, terdiri dari aktivitas yang diskrit yang mentransformasikan input menjadi output. Model ini dapat diterapkan untuk pemodelan bisnis, pemrosesan data, dan sistem manufakturing, (Indrajit dan Djokopranoto, 2002).

Pemetaan proses bisnis dilanjutkan dengan diagnosis proses kritis dalam sistem industri. Diagnosis dilakukan dengan pemetaan Value stream mapping (VSM). VSM adalah salah satu teknik Lean untuk menganalisis aliran material dan informasi yang dibutuhkan sampai dihasilkan produk atau jasa kepada konsumen. Value Stream Mapping juga disebut Material and Information Flow Mapping. Peta ini memuat informasi proses, aliran material dan informasi dari satu famili produk tertentu dan membantu mengidentifikasi pemborosan dalam sistem. (Liker, et al, 2004). Sedang Womack, et al. (1996) menyatakan langkah dalam memetakan aktivitas adalah dengan mengidentifikasi famili produk. Famili produk merupakan sekumpulam produk yang memiliki tahapan dan menggunakan mesin yang sama dalam pemrosesan. Famili produk ditentukan dengan menggunakan $P Q R$ Analysis. Langkah selanjutnya adalah menemukan masalah yang terjadi dan menyususn peta aliran nilai untuk situasi eksisting atau VSM Current Statesebagai refleksi kondisi nyata di industri. 


\section{METODE PENELITIAN DAN PEMBAHASAN}

\subsection{Metode Penelitian}

Penelitian ini dilakukan secara studi kasus pada beberapa unit industri penyamakan kulit di Sukaregang. Obyek penelitian adalah industri penyamakan kulit berskala menengah, yaitu industri pengolahan kulit dari bahan kulit sapi dan industri pengolahan dari bahan kulit domba. Proses diawali dari pemetaan proses bisnis di industri kulit secara umum. Selanjutnya dilakukan pendataan proses dengan mempelajari, memahami, menganalisis serta memecahkan masalah berdasarkan fenomena yang ada. Agar penelitian berjalan dengan baik dan terarah diperlukan kerangka penelitian yang didalamnya berisi suatu gambaran dari langkah - langkah yang harus dilakukan dalam penelitian, dari tahap awal sampai dengan tahap akhir.

\subsection{Pemetaan Proses Bisnis}

Penggambaran proses bisnis atas situasi nyata di perusahaan yang sedang diperlukan sebagai acuan untuk mengembangkan evaluasi dalam sistem operasi yang ada. Dengan pemetaan maka proses bisnis dapat didokumentasikan., dan dapat diketahui kelemahan - kelemahan yang dapat menghambat aktivitas bisnis perusahaan sehingga dapat dijadikan sebagai dasar untuk melakukan perbaikan proses bisnis agar dapat meningkatkan produktivitas perusahaan yang pada akhirnya akan mengoptimalkan keuntungan.

Pengumpulan data melalui survei dan wawancara untuk menemukan proses proses kritis. Data berupa informasi proses bisnis melalui interview atau survey kepada stakeholder (pengelola industri, konsumen, aparat pemerintah). Mengidentifikasi prosesproses yang kritis (kurang efisien, kurang mempunyai nilai tambah, dirasakan kurang nyaman). Menganalisis hasil identifikasi proses-proses yang dianggap kritis. Indikator capaian pada tahap ini yaitu terbentuknya model proses bisnis perusahaan industri kulit pada kondisi saat ini dan teridentifikasinya proses - proses kritis.
Selanjutnya dilakukan analisis untuk membangun model proses bisnis sebagai perbaikan bagi kinerja industri kulit. Rancangan model perbaikan berdasarkan solusi atas proses - proses kritis. Menyusun alternatif perbaikan model.

\subsection{Pembahasan}

Sentra Industri Penyamakan Kulit Sukaregang Garut merupakan sentra Industri Penyamakan Kulit terbesar di Indonesia. Kegiatan industri Sukaregang terutama sejak 1989 dan secara turun temurun usaha tersebut berkembang sampai sekarang. Produk utama industri Sukaregang adalah kulit untuk pembuatan produk sepatu, Jaket, tas, ikat pinggang, macam - macam dompet, serta produk jadi dari kulit lainnya. Dalam kegiatan produksinya, industri di Sukaregang menggunakan bahan baku kulit Domba dan Kulit sapi mentah garaman yang sebagian besar didatangkan dari luar Garut. Bahan baku diperoleh melalui agen pengumpul kulit dari wilayah Bogor, Sukabumi, Jakarta, Bandung, serta daerah - daerah lain di luar Jawa Barat.

\subsection{Pemetaan Proses Bisnis dengan IDEF0}

Penggambaran proses bisnis industri penyamakan kulit sebagai acuan untuk mengembangkan solusi perbaikan kinerja industri. Pemetaan proses bisnis di dokumentasikan agar diketahui kelemahan kelemahan yang menghambat aliran bisnis, upaya untuk meminimasi atau menghilangkan hambatan sebagai dasar untuk melakukan perbaikan proses bisnis sehingga dapat meningkatkan produktivitas dan pada akhirnya memberi nilai tambah berupa keuntungan. Proses bisnis Industri Penyamakan Kulit dengan menggunakan tools IDEF 0 level 0 dapat dilihat pada gambar 1. Selanjutnya proses diuraikan lagi pada level berikutnya untuk informasi lebih detail. Pemetaan meliputi aspek input, mechanime, control, serta output dari aktivitas bisnis ini maka dapat diuraikan sebagai berikut : 


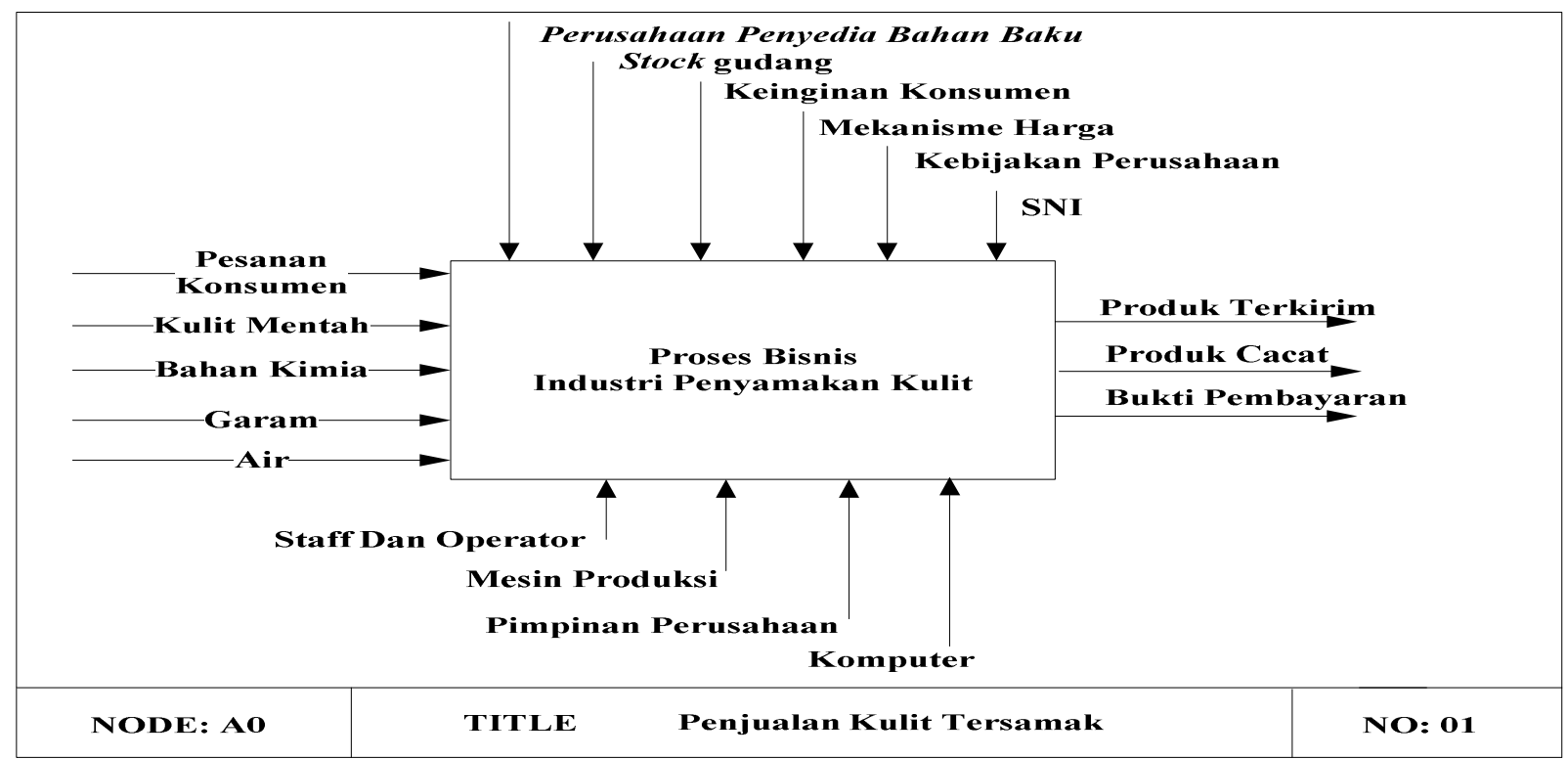

Gambar 1. Proses Bisnis Industri Penyamakan Kulit.

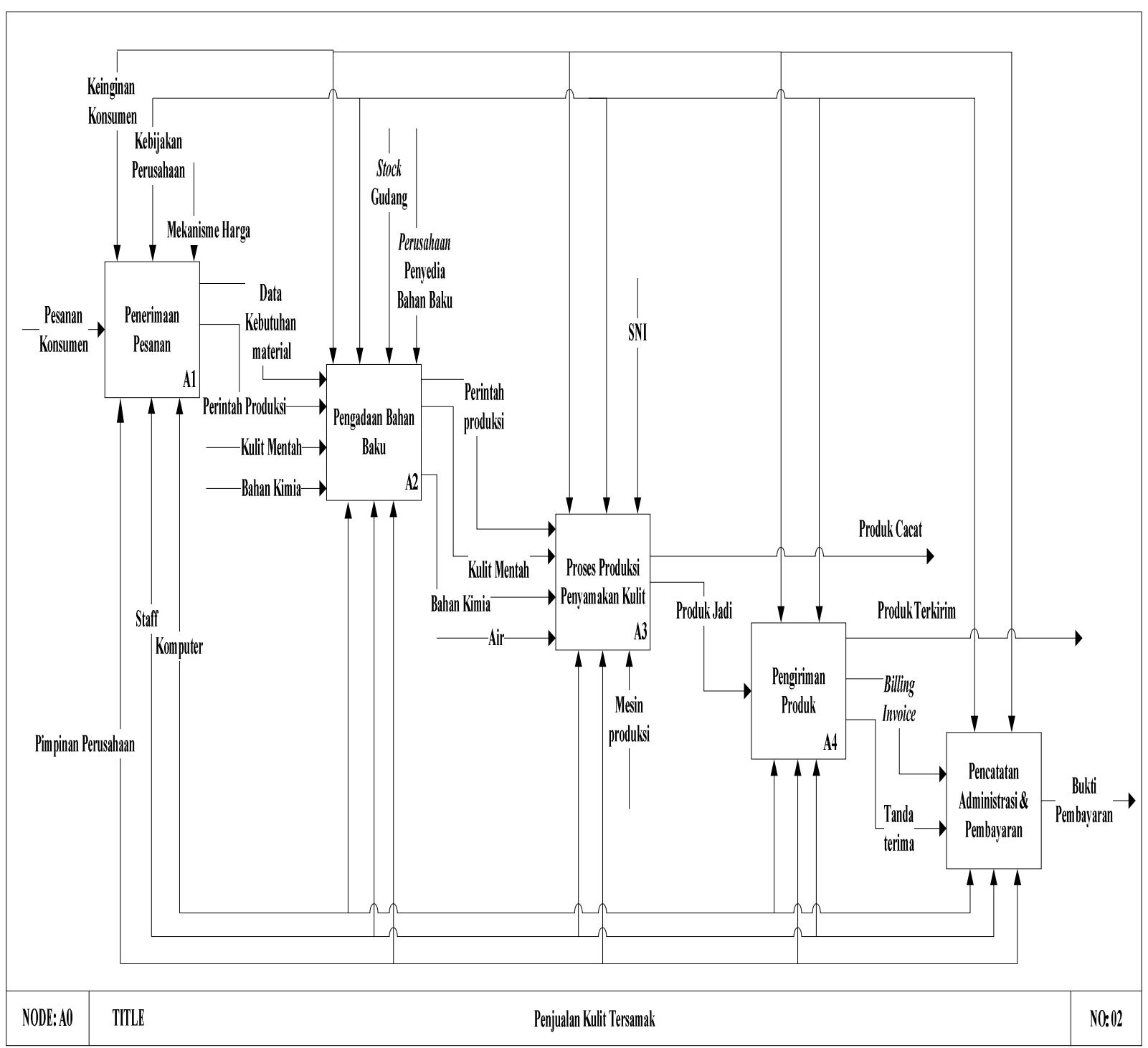

Gambar 2. Pemetaan Proses Bisnis Industri Penyamakan. 


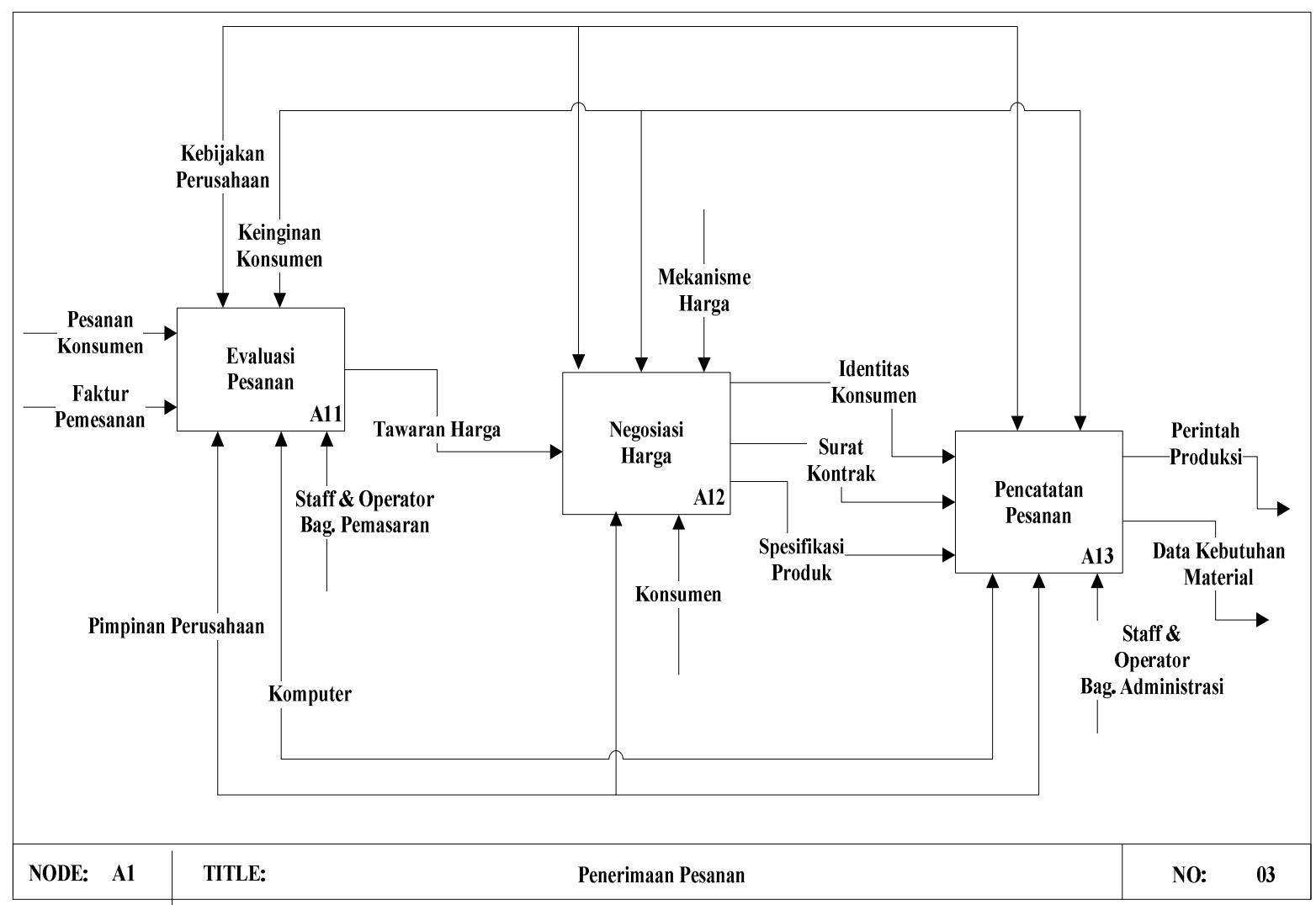

Gambar 3. Pemetaan Proses Bisnis Sub Aktivitas Penerimaan Pesanan (A1).

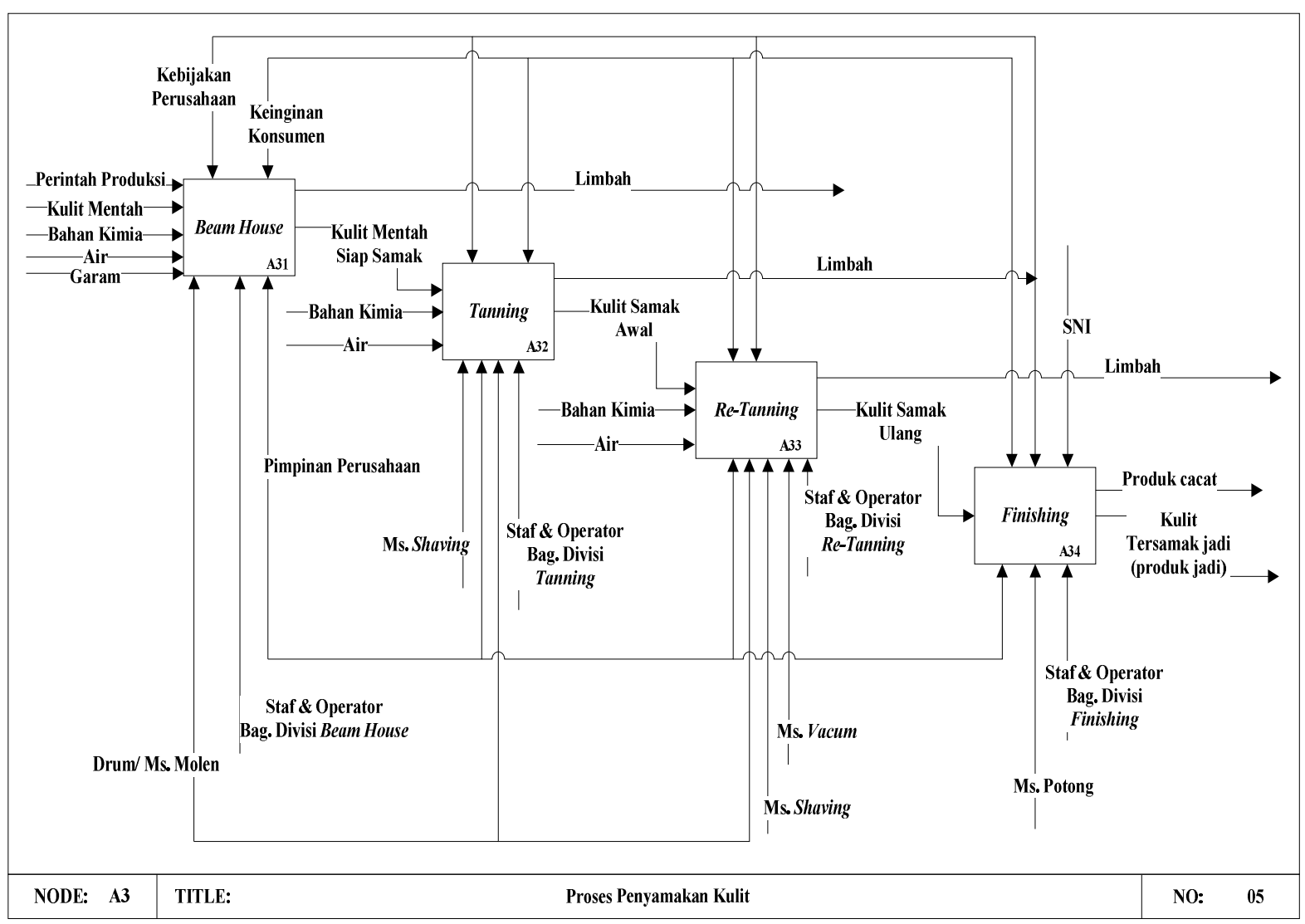

Gambar 4. Pemetaan Proses Bisnis Sub Aktivitas Proses Produksi Penyamakan Kulit (A3). 


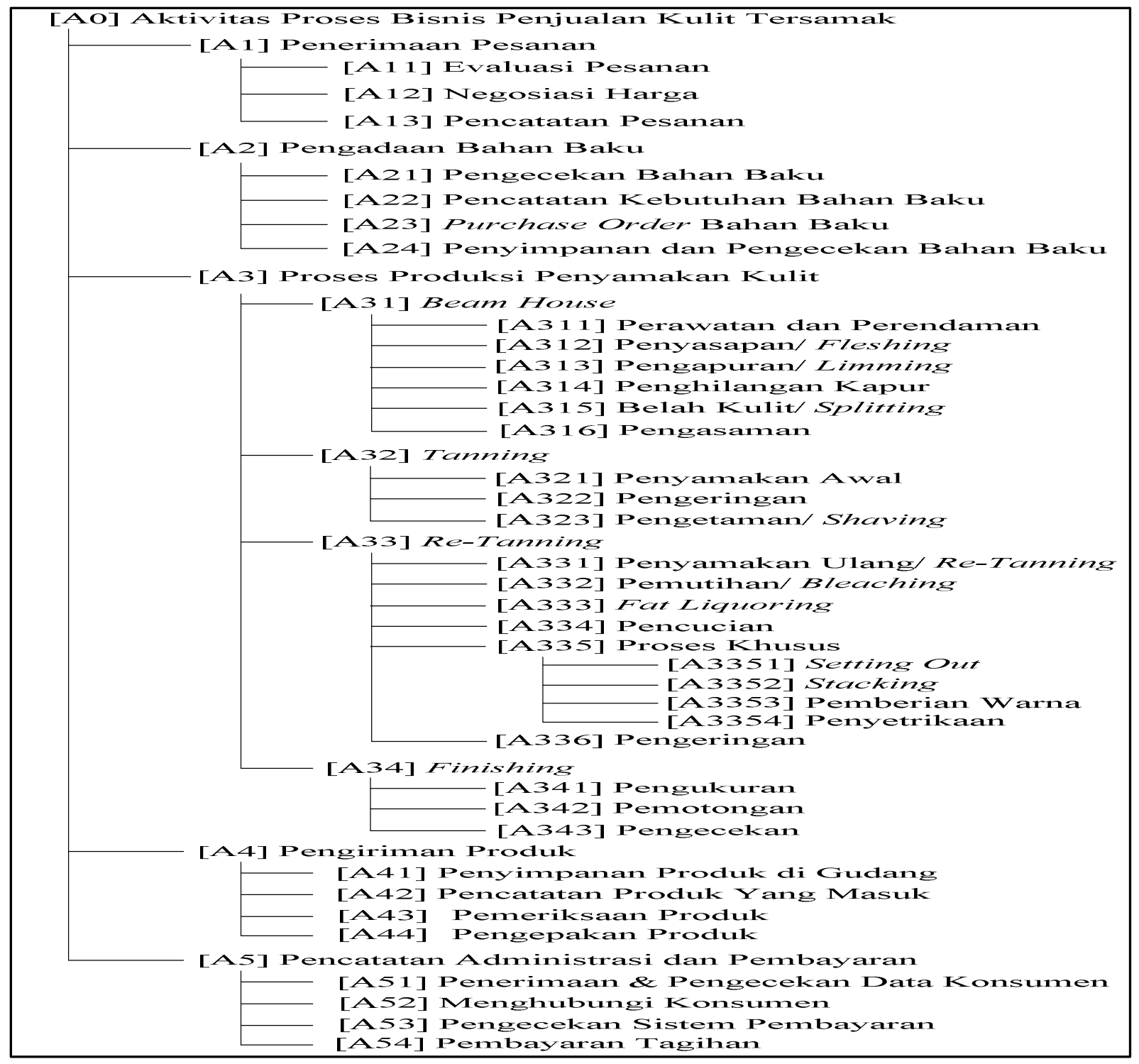

Gambar 5 Pohon Proses Bisnis Industri Penyamakan Kulit.

Hasil pemetaan pada proses berikutnya sebagai turunan dalam proses bisnis yang lebih rinci, sesuai lingkup operasi. Peta proses ditunjukan gambar 2, 3, dan 4 diatas.

\subsection{Diagnosis Proses - proses Kritis dan Identifikasi Permasahan pada Industri Penyamakan Kulit dengan Value Stream Map - Current State}

Hasil pemetaan dengan IDEF0, kemudian dilanjutkan dengan Value Stream Mapping untuk memperlihatkan waktu proses keseluruhan sekaligus mengidentifikasi proses - proses mana yang memberikan nilai tambah dan proses - proses mana yang tidak memberikan nilai tambah.
Value Stream Map (VSM) untuk kondisi awal diperlihatkan pada gambar 6. Hasil pemetaan ditemukan permasalahan kritis pada industri penyamakan kulit. Dengan pemetaan proses sebuah organisasi memiliki dokumentasi mengenai pekerjaan yang dilakukan, sehingga memungkinkan untuk menganalisa pekerjaan yang telah dilakukan bagi peningkatan kepuasan pelanggan melalui identifikasi terhadap pengurangan waktu proses, mengurangi produk defect, mereduksi biaya, mereduksi tahapan proses yang tidak menghasilkan nilai tambah, meningkatkan produktivitas, dan memudahkan pengukuran performansi. Hasil pemetaan ditunjukkan pada gambar 6 . 
Tabel 2. Identifikasi Proses-proses Kritis Industri Penyamakan Kulit

\begin{tabular}{|c|c|c|c|}
\hline No & Kode & Proses Kritis & Permasalahan \\
\hline 1 & $\mathrm{~A} 2$ & $\begin{array}{c}\text { Pengadaan Bahan } \\
\text { Baku }\end{array}$ & $\begin{array}{l}\text { Kekurangan suplai bahan baku kulit, lamanya } \\
\text { waktu pemesanan dan kedatangan yang bergantung } \\
\text { kepada prosedur impor (lebih dari } 20 \text { hari sampai } \\
\text { dua bulan) }\end{array}$ \\
\hline 3 & A4 & $\begin{array}{l}\text { Proses Penyamakan } \\
\text { Kulit }\end{array}$ & $\begin{array}{l}\text { Kekurangan pasokan kulit mentah berdampak } \\
\text { kepada seleksi Kualitas kulit tersamak tidak baik } \\
\text { sehingga semua bahan diproses meski ada yang } \\
\text { kurang atau grade-3. } \\
\text { dan Utilitas fasilitas produksi tinggi } 49 \% \\
\text { menganggur. } \\
\text { Hasil pemetaan VSM menunjukkan terdapat } \\
\text { wasting proses sebagai waktu tidak produktif } \\
\text { sebesar } 465 \text { menit dalam satu siklus. Hal ini } \\
\text { membutuhkan solusi perbaikan } \\
\text { Kualitas kulit yang tersedia baik grade-1 garde-2 } \\
\text { dan grade-3 sebagai hasil proses dalam satuan lot, } \\
\text { sehingga produk grade-3 dapat menururnkan } \\
\text { kualitas itas aspek utilisasi dan inefisiensi } \\
\text { Selain itu an } \\
\text { mengakibatkan keterlambatan dalam pengiriman } \\
\text { produk kepada pihak pembeli }\end{array}$ \\
\hline
\end{tabular}

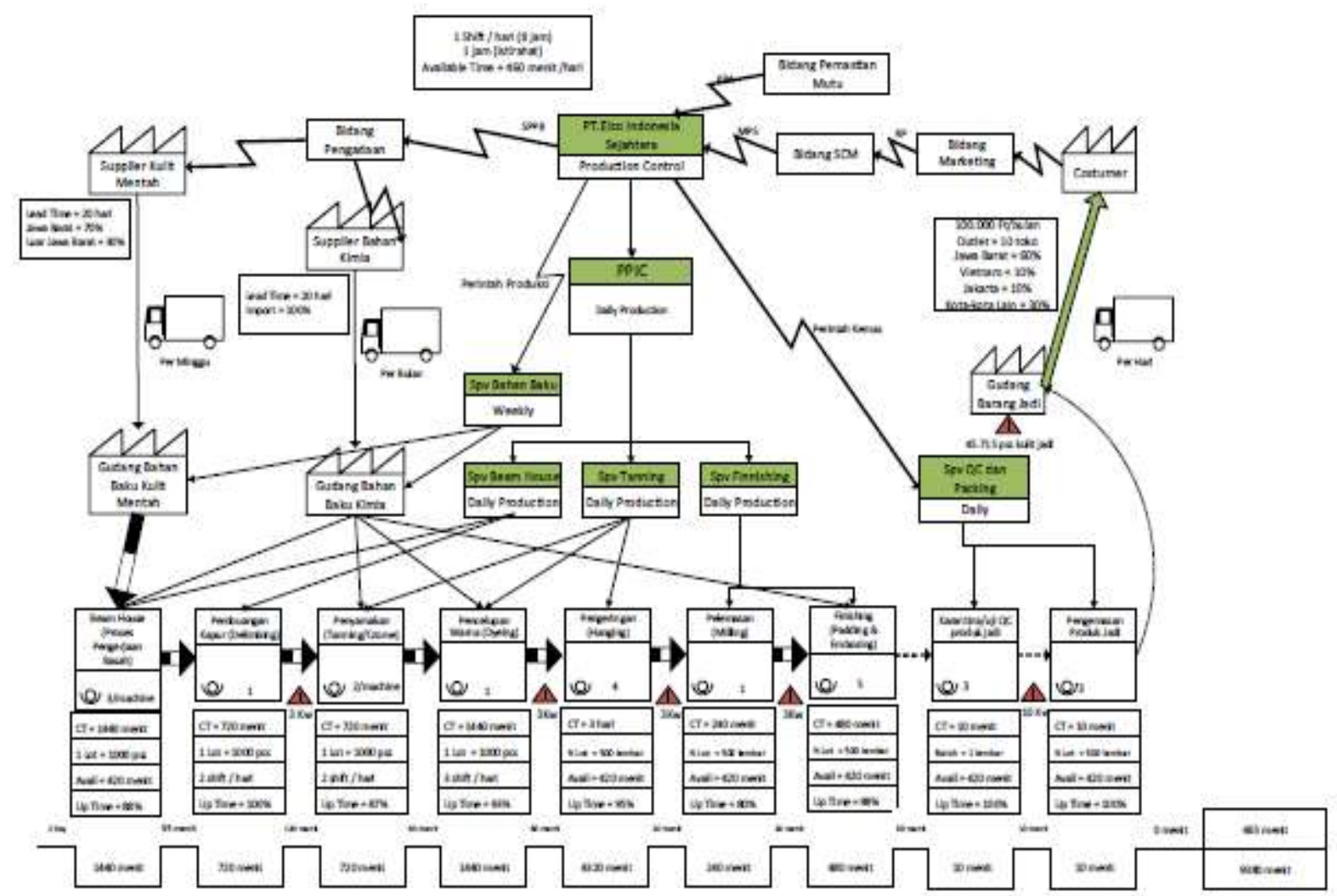

Gambar 6. Proses Bisnis Dalam Rantai Hubungan Nilai Antar Pihak Terkait. 
Adapun hasil analisis ditunjukkan diperlihatkan pada tabel 2 diatas. Untuk menyelesaikan permasalahan yang ditemukan, maka dilakukan analisis faktorfaktor penyebab munculnya permasalahan tersebut.

\section{KESIMPULAN}

Dalam beberapa tahun terakhir industri kulit mengalami kekurangan pasokan bahan baku kulit. Kondisi ini berdampak kepada utilisasi pabrik penyamakan rendah. Kekurangan pasokan bahan baku juga menyebabkan penyamak berusaha memperoleh bahan baku meskipun dengan kualitas yang tercampur. Hal ini menyebabkan kualitas sebagian kulit tersamak yang dihasilkan juga tidak baik. Sedangkan berdasar analisis atas proses kritis, industri kulit Sukaregang masih belum efisien, dimana proses produksi belum menerapkan konsep lean manufacturing dalam aspek pemeriksaan bahan baku, dan proses loading unloading dalam tanning drum.

Pada aspek integrasi Supply Chain kinerja dalam hubungan antar pengusaha dalam asosiasi penyamak kulit kurang terjalin kerjasama. Dengan demikian hasil analisis rantai nilai dan aliran supply chain baik secara internal pabrik dan hubungan integrasi antar industri belum berjalan secara efisien. Oleh karena itu dibutuhkan solusi lebih lanjut secara terintegrasi baik secara internak manufaktur juga dsalam hubungan antar pengusaha dalam sentra industri kulit Sukaregang.

\section{DAFTAR PUSTAKA}

Agus, A., dan Hajinoor, MS, "Lean production supply chian management as driver towards enhancing product quality and business performance-Case study of manufacturing companies in Malaysia", International Journal of Quality \& Reliability Management, Vol. 29, No.1, 2012.

Badan Pusat Statistik, Data Strategis Statistik Indonesia, BPS, Jakarta, 2015.

Cudney, E., dan Elrod, C, "A comparative analysis of integrating lean concepts into supply chain management in manufacturing and service industries", International Journal of Lean Six Sigma, Vol.2, No.1., 2011.

Departemen Perindustrian., Road Map Industri Alas Kaki - 2007, www.depperin.go.id/ind/publikasi/petaja lan/alas_kaki.pdf, tanggal 26 Februari 2008.

Dinas Perindagkop UKM Kabupaten Garut, 2014, Data Potensi Industri di Kabupaten Garut Tahun 2013.

Dora, M., et al, "Adoptability of Lean Manufacturing among Small and Medium Food Processing Enterprises", Proceedings of the 2012 Industrial and Systems Engineering Research Conference., 2012.

Indrajit, R. E. dan Djokopranoto, R, Konsep \& Aplikasi Business Process Reengineering, Jakarta, PT. Grasindo, 2002. 
Kemenperin, Peraturan Pemerintah Nomor 14 Tahun 2015 tentang Rencana Induk Pembangunan Industri Nasional Tahun 2015 - 2035, Jakarta, 2015.

Liker, J. K., , The Toyota Way, Penerbit Erlanga, Jakarta, 2004.

So, S., dan Sun, H, "Supplier integration strategy for lean manufacturing adoption in electronic-enabled supply chains", Supply Chain Management : An International Journal., 2010.

Tyasti, Avia E dan Hutabarat, VHO, Industri Padat Karya Pada Industri Barang Jadi Kulit, Percepatan Penerapan Paket Kebijakan Ekonomi Jilid VII, MBA ITB., 2016.

Unit Pelayanan Teknis Dinas (UPTD) Departemen Perindustrian Jawa Barat, Data Potensi Sentra Industri Kulit Sukaregang, Garut, 2014.

USAID, Profil Spesifikasi Kulit Tersamak Indonesia 2007 Indonesian Leather Specifications Profile, 2007.

Womack, J. P., Jones, D.T., \& Roos, D, The Machine That Changed The World, Harper Collins, New York, 1990. 